\title{
Understanding Curriculum as Phenomenon, Field, and Design: A Multidimensional conceptualization ${ }^{i}$
}

\begin{abstract}
Summary: This paper searches for an understanding of curriculum as a phenomenon, a field, and a design process. Curriculum is a complex phenomenon. Curriculum is also an "interdisciplinary academic field devoted to understanding curriculum" (Pinar, 2011, ix). In addition, curriculum also refers to the process of design through which the content of schooling is verified. The context of my endeavour is teacher education. In fact, thinking about curriculum becomes even more complex when thinking about how to teach it to future teachers. It seems to me that at this level we cannot avoid to assume a pluralistic view of the field thinking what is its historical legacy, including the major gap between curriculum theory and curriculum development. Therefore, the field of curriculum studies has changed by incorporating different dimensions to the concept of curriculum, making it a layered or multidimensional concept. I argue that a multidimensional concept of curriculum can be a powerful theoretical tool for understanding curriculum, to organized and create knowledge about it, and to inform the process of curriculum design.
\end{abstract}

Keywords: multidimensional curriculum, curriculum studies, curriculum design, curriculum research.

Резюме (Даниель Ф. Джонсон-Мардонес: Понимание учебного плана как феномена, сферы деятельности и дизайна: многомерная концептуализация): Данная статья рассматривает понимание учебного плана как феномена, сферы деятельности и процесса дизайна. Образовательная программа представляет собой комплексный феномен, а также "междисциплинарную область науки, посвященную пониманию учебного плана" (Пинар 2011, икс). Кроме того, учебный план относится к процессу конструкции, через который верифицируется содержание образования. В рамках моего исследования рассматривается педагогическое образование. Оказывается, что размышления об образовательной программе становятся более затруднительными, когда речь идет о том, как передать ее будущим учителям. При плюралистическом рассмотрении данного вопроса на данном уровне мне кажется неизбежным вопрос о его историческом наследии, включая большие пробелы между теорией учебного плана и его развитием. В связи с этим в области исследований учебного плана произошло включение различных многоступенчатых концепций учебного плана. Я думаю, что многомерная концепция учебного плана может стать мощным инструментом теоретического понимания, организации, усвоения и передачи знаний об учебном плане и процессе его создания.

Ключевые слова: многомерные учебные планы, исследования учебного плана, дизайн учебного плана, исследование учебного плана

Zusammenfassung (Daniel F. Johnson-Mardones: Das Verständnis des Lehrplans als Phänomen, Arbeitsbereich und Design: Eine multidimensionale Konzeptualisierung): Dieser Artikel hinterfragt das Verständnis des Curriculums als Phänomen, Arbeitsbereich und Design-Prozess. Das Curriculum ist ein komplexes Phänomen sowie auch ein "interdisziplinärer Wissenschaftsbereich, dem Curriculum-Verständnis gewidmet" (Pinar 2011, ix). Darüber hinaus bezieht sich Curriculum aufden Prozess der Konstruktion, durch den der Bildungsinhalt verifiziert wird. Der Rahmen 
meiner Untersuchung ist die Lehrerbildung. Es erweist sich, dass das Nachdenken über das Curriculum noch komplexer wird, wenn es darum geht, wie es künftigen Lehrern zu vermitteln ist. Wenn wir eine pluralistische Betrachtung dieses Bereichs anstreben, scheint es mir auf dieser Ebene unvermeidbar, nach seinem historischen Erbe, einschließlich der großen Lücke zwischen Lehrplan-Theorie und Lehrplan-Entwicklung zu fragen. Deshalb erfolgte im Bereich der Curriculum-Studien die Einbeziehung unterschiedlicher, mehrstufiger Lehrplankonzepte. Ich meine, dass ein multidimensionales Curriculum-Konzept ein leistungsfähiges Werkzeug sein kann für das theoretische Verständnis, für die Organisierung und die Aneignung und Vermittlung von Wissen über das Curriculum und den Prozess seiner Gestaltung.

Schlüsselwörter: mehrdimensionale Lehrpläne, Curriculum-Studien, Curriculum-Design

\section{Introduction}

The main question in the field of curriculum seems to be "What is curriculum?" The polysemy of the concept has been traditionally pointed out by listing the multiple definitions that the authors in the field have offered over time. These definitions have been organized, for instance, by distinguishing between those that can be labelled as prescriptive and those that can be termed descriptive. In the field of curriculum, prescription abounds while descriptions scarce, Stenhouse affirmed in England, beginning the 1970's. The same criticism has been taking place in the United States from the late 1970 's for those concerned by a field dominated by the so-called Tyler rationale. Since then, Jackson would name a hidden curriculum taking place in schools, Schwab would call for the practical as the language of curriculum, and the next decade would bring a vibrant scholarship seeking to reconceptualize the field. All that brought up a proliferation of new definitions. Those definitions were put into to classifications and typologies, which proliferated just as the definitions did. The field became a very complicated conversation.

In the United States, the crisis of the Sputnik and the educational reform in the 1960's, among other factors, co-helped to provoke a main gap in the field: the gap between curriculum development and curriculum theory. The latter was no longer concerned with the development of curriculum prescription, but with understanding curriculum as lived educational experience. Kridel (2010) has argued that curriculum studies "designates a shift of theory and practice as scholars sought understanding of curricula as a phenomena of interest and societal import in contrast with sole concentration on service to leaders of practice in schools" (p. 230). As a result, the field of curriculum studies has been fractured, broadly speaking, among those working in curriculum design and those doing curriculum theory. Therefore, this complicated field has been incapable of, and reluctant to, offering a unified view of the field. This is not a problem by itself but definitely becomes an issue when we situate our reflection upon teacher education. In fact, thinking about curriculum becomes even more complex when thinking about how to teach it to future teachers. It seems to me that at this level we cannot avoid to assume a pluralistic view of the field thinking what is its historical legacy, including the major gap between curriculum theory and curriculum development. In this regard, having teacher education in mind, I unavoidably and indirectly address some "unpacking curriculum controversies" (Cochran-Smith \& Demers, 2008, p. 261) and reflect about what remains in the field.

With that in mind, I address in this paper the challenge of developing a concept of curriculum that might help to understand curriculum as a phenomenon, curriculum as a process of design, and curriculum as a field. My hunch is that this can be made by looking at the history of the field and its multiple conceptualization of the curriculum phenomenon and organizing them in as if every type were a dimension of a complex phenomenon. This, I believe, would not only be of some help in the field of teacher education but also may help to build our capacity of taking across within the field of education including policy makers. The pedagogical concern both in teacher education and schooling 
as a public sphere informs this search for a multidimensional concept of curriculum that allows to understand curriculum as a phenomenon, as design and as field.

\section{Curriculum as an Academic Field}

Beginning the second decade of the 21st Century, curriculum is established as a divergent field moving in different directions (Pinar, 2011). This is the weakness and strength of the field "that (supposedly) is there to help us think rigorously about what and whose knowledge is of most worth" (Apple, 2010, p. 100). These centripetal tendencies are certainly a consequence of the field's history during the last decades of the Twentieth Century. This history is marked by the reconceptualization of curriculum studies in the United States and the incorporation of phenomenology, existentialism, psychoanalysis, critical theory, biography, gender, race, and class analysis, postmodernism, poststructuralism, and so on, in the project of understanding curriculum. The three decades of the last Century we times of expansion for the field of curriculum. Those times of expansion permitted curriculum studies to surpass the theoretical feature of the field and to some extend to advance in overcoming its, in Kliebard's (1977) words, disturbing "lack of historical perspective" (p. 55). This historical understanding needs still to be explored, both in the US and other contexts. As Pinar (2011) has argued, becoming historical "restores the field's historic concerns as historic," (p. 111) connecting us with our legacy. Therefore, looking inward and backward in the field would make possible "finding some common cause and common understanding across our vast landscape of difference" (Hlebowitsh, 2009, p. 15).

Working from a historical perspective, Shubert (2010) has suggested that there is a "tension [in curriculum studies] between the expansion of curriculum ideas and the need to summarize them for dissemination," say in teacher education programs, graduate programs in curriculum studies, professional development for in-service teachers, educational administrators and supervisors, policy makers, and so on. Furthermore, Schubert (2010) claims that these "expansive and synoptic dimensions of the field complement one another" (p.18). If so, this synoptic reconstruction in curriculum studies should be undertaken by understanding the main conceptual contribution to the field as shedding light onto a dimension of the complex curriculum phenomenon. What is possible to come out of that process is an understanding of a field that has changed by incorporating different dimensions to the concept of curriculum, making it a layered or multidimensional concept. These different dimensions are emphasized by different curriculum discourses that can be conceptualized as research space opened by scholars concerned with understanding curriculum. The organized view of the field, resulting from that endeavour, provides possibilities of dialogue with other fields within the field of education such as educational policies, teacher education, and subject-matter oriented fields. This view connects curriculum theory and curriculum design, as well as facilitates the research in the field to be enriched by the field's conceptual development, and vice versa.

\section{Curriculum as a Phenomenon}

Curriculum is a complex phenomenon. This complexity makes the curriculum a complex as well as controversial endeavour (Pacheco, 2012). However, this complexity has not always been addressed as such. Under the dominance of curriculum development, curriculum was defined as written or official curriculum. The word "written" emphasized the curriculum's feature of being a document: a document that regulates the content of schooling, shapes the school experience, and controls teachers' work. This written document was conceived as a selective tradition that one generation passes through to the next. Curriculum is a document of identity, as the Brazilian curriculum scholar Tomaz Tadeu Da Silva (1999) reminds us. This narrow conceptualization of curriculum, as a written official 
prescription and only a course of study, was called into question during the 1960's. Life in Classrooms (Jackson, 1968) was probably the first text that explicitly affirmed that what students learned at school was something more than just the official or written curriculum. Through schedules, routines, and school rituals students learned what Jackson called a hidden curriculum. Ever since, different types of curriculum have been named: hidden curriculum (Jackson, 1968; Apple,1970); ideal curriculum, formal curriculum, perceived curriculum, operational curriculum, experiential curriculum (Goodlad, 1979); explicit, implicit, and null curricula (Eisner, 1979); recommended, written, supported, taught, tested, hidden, and learned curricula (Glatthorn et al, 2006). Again, different criteria for classifying curriculum types pointed to different dimensions of this complex phenomenon. They are no more than an expression of the complexity of curriculum which "has intended, taught, embodied, hidden, tested, and null dimensions" (Shubert, 2008, p. 410). Ever since, different types of curriculum have been named, making curriculum a much more "complicated conversation" (Pinar, 1995).

\section{Curriculum as design}

Having conceptualized curriculum as a complex phenomenon and pointed the expansive and synoptic dimensions of the field of curriculum, now it is the time to connect this reflection to the problem of curriculum design. Curriculum development has typically emphasised the written dimension of curriculum as prescription. The development of a curriculum is more or less a matter of implementation taking place when the written curriculum has been formulated. Under Tyler rationale, this process is a technical task that teachers should address by developing what has already been decided and will be tested. Bloom's taxonomy was the perfect tool to accomplish that goal. This tool provided an uncritical procedure in which teachers could develop curriculum by choosing a series of verbs associated with different skill levels, formulating more and more specific objectives, which would allow measuring those educational goals. In this approach, teachers were not curriculum makers (Connelly \& Clandinin, 1991) but technical developers of curriculum decisions already made by the designers of a teacher-roof curriculum. In that sense, Grimmett and Halvorson (2010) have claimed that what was missing in the process of reconceptualization was "to re-conceptualize the process by which curriculum is created," (p. 241) failing to frame "the creation of non-technicist curriculum" (p. 242). As a result, curriculum design has remained under a technical or instrumental approach. The practice of developing curriculum is part of schooling, and curriculum reform remains a main component of every educational reform. Therefore, Pinar (2013) would add, "the inability of the field to intervene in so-called school reform undermines any sense of professional and individual agency" (p. 3 ). As we see, the challenge of curriculum design is a concern across camps in the landscapes curriculum studies.

Acknowledging the complexity of curriculum as a phenomenon, curriculum design is conceived as a complicated decision making process that has technical, practical, and political implications. It is technical because it seems improbable that we can think of a school system without curriculum regulations, guides, and other documents that shape teaching. It is practical because practitioners make decisions about desired, or not, effects of these curriculum prescriptions, but also because there are aspects of the practical that escape and resist technical rationales. It is political because curriculum constrains the world view or views to which students will be exposed as part of their school experience.

Therefore, curriculum design needs to incorporate the field's legacy while moving from the idea of curriculum development to a conception of curriculum design. Curriculum design should become also multidimensional. In designing curriculum at national, state, district, school, or classroom level, 
we should include every dimension of the curriculum phenomenon such as the written curriculum, the taught curriculum, the hidden curriculum, the learned curriculum, and so on. All these dimensions should be included as a variable or set of variables in the deliberative process of decision-making. In design, as a decision-making process, curriculum reaches school and classroom levels. In that process, a collective act of "educational imagination" (Eisner, 1979) takes place. Through this "educational imagination", educators address the endeavour of enriching students' school experience.

\section{A Precarious Multidimensional Concept of Curriculum}

This multinational concept is precarious because is based on the curriculum history in the US; it also precarious as a reminder of that every conceptualization opens a space of meaning, while closing others. Being aware of this situation is essential in order to acknowledge the uncertainty, complexity, and unpredictability of curriculum practices and contexts. Consciousness of this precariousness is essential for the expansive and the synoptic dimensions of curriculum studies to complement one another. Under that understanding, I propose a multidimensional concept of curriculum which includes intended, non-intended, and experienced or lived curriculum.

The intended dimensions comprise those dimensions that are explicitly deployed by the older generation as part of what they want to convey to the younger generation. The intended dimensions comprise the official prescription, but also come about in the process of verification of any prescription. Therefore, four aspects of curriculum are considered to be intended curriculum. This intended dimensions are the written, the supported, the taught, and the tested. The written dimension implies the formulation and content of the written document that prescribes what should be taught at schools. The written dimension should include the national curriculum, but also those written documents at state, district, and school levels. The supported dimension composes all those aspects that make possible the actualization of any curriculum prescription. It is curriculum as embodied in materials "in which the content is selected, organized, and transformed for social, cultural, educational, curricular, and pedagogical purposes" (Deng, 2011, p. 538). It is the result of the process by which scholarly materials are translated into curriculum materials. Glatthorn et al. (2006) mention textbooks as an important component of supported curriculum. The taught dimension is the curriculum as is understood and put into practice by teachers. This is the curriculum as it is actually delivered by teachers, reinvented. As it has been said, "at some point, the design of the curriculum leaps off the paper and takes on a life in the school curriculum" (Hlebowitsh, 2009, p. 22). Finally, the tested dimension has to do with the forms of evaluations that students are asked to take by their teachers, the school, the district, the state, the central government, and even by international organizations in order to assess how well the prescribed curriculum has been learned by students. However, these evaluations also teach what is considered important in the classroom, school, society, and the world. Summarizing, the written, supported, taught, and tested dimensions of curricula are parts of the educational intention.

On the other hand, there are also non-intended, or at least non-explicit, aspects of curriculum. Those dimensions situates beyond the explicit educational intention. There, we find the hidden and null dimension of curriculum. The hidden dimension is what school teaches without teaching it. The null dimension is what is left outside of the official curriculum, what is not taught. In this sense, Glatthorn et al (2006) write:

Certain important aspects of the hidden curriculum are so intrinsic to the nature of schools as a cultural institution that they might be seen as constants. The depiction of those constants presented below has been influenced by a close reading of several authors: curricular Reconceptualists such as 
Apple (1979), Pinar (1978), and Giroux (1979); sociologists such as Dreeben (1968); and educational researchers such as Jackson (1968) and Goodlad (1984). One of the constants of the hidden curriculum is the ideology of the larger society, which permeates every aspect of schooling. Thus, schools in the United States inevitably reflect the ideology of democratic capitalism. (p. 23)

Finally, the experienced or lived curriculum dimension is a combination of the intended and the nonintended curriculum dimensions, but also exceeds that. It is the curriculum from the point of view of the student. Not the imagined student of policy documents, academics projects, or parents desires but the actual student in all his-her humanness. "The experienced curriculum expands attention to thoughts, meanings, and feelings of students as they encounter it" (Schubert, 2008, p. 409). In a more restrictive perspective what can be considered the experienced or lived curriculum is what Glatthorn et al (2006) names the learned curriculum. The learned curriculum is what students have actually learned in school: a combination of the intended and hidden curriculum. By discussing the experienced or lived curriculum, they make the point of thinking about the curriculum from the point of view of the student. Then curriculum becomes a complicated conversation about one's educational experience, as Pinar (2011) has argued.

\section{The Potential of a Multidimensional Concept in Curriculum}

Curriculum studies are an intellectual tradition within the field of education. Its institutional location is within schools of educations; it is a common course in teacher education programs. There exists a responsibility to convey the history and traditions, as well as the main concepts, of curriculum to newcomers to education. That is the pedagogical possibility that a multidimensional concept of curriculum presents. The potential of offering an organized view of the field, based on its intellectual contributions, it's a pedagogical endeavour that those who advocate for the educational field cannot ignore. This multidimensional concept it is part of the synoptic dimension of the field of curriculum studies that synthetized curriculum thought for dissemination (Schubert, 2008). This dissemination has teacher education and teachers' professional development two main sites -sites in which curricularists usually conduct their work. Efforts in that direction have certainly been made.

In addition, since each of these dimensions also rely on the role of different individuals within an educational system, the same work can be done from many points of view, providing insights to bridge the gap between the academic work and the practice of curriculum. Therefore, the consideration of these individuals around specific issues or programs make it possible to include the following individuals and groups in the analysis: the Government (written curriculum); Owners, administrators and publishing companies (supported curriculum); Teachers (taught curriculum); Teachers, government, and assessment agencies (tested curriculum); and Students (lived curriculum). The complexity of the curriculum phenomenon, thus, is also acknowledged in terms of the various participants in the field.

It is promising to think about this multidimensional concept as both curriculum and phenomenon, as a field and as a design. This brings about connections between the theoretical development of the field and specific research areas that inform how each dimension of the curriculum phenomenon is actualized in each specific context. Therefore, in addition to offering a multidimensional conceptualization of the curriculum phenomenon - a conceptualization consistent with the complex nature of curriculum - a theoretical foundation for continued research emerges, which may provide the description of each curriculum dimension. Even more, this research should include the relations among those dimensions in particular contexts: the written, supported, taught, tested, hidden, null, and ex- 
perience curriculum. This research could also permit the considerations of diachronic and synchronic, as well as their interconnections, giving an even more comprehensive view of curriculum. This intellectual endeavour is not a call to abandon theoretical work in curriculum; theory, after all, "is the result of our desire to create a world [or field] we can understand" (Eisner, 1985, p. 29).

\section{Final remark}

The field of curriculum studies has grown by incorporating different dimensions to the concept of curriculum, making it a layered or multidimensional concept. A multidimensional concept of curriculum can be a theoretical tool to understanding curriculum, to create knowledge about it, and to inform curriculum design. This multidimensional perspective could, then, inform a research program to understand curriculum locally, nationally, and globally, providing a baseline of knowledge about curriculum that everyone in the field should be familiar with and, more importantly, a minimum of curriculum knowledge to be passed to the next generation. Whether or not this minimum has been reached is something that every intellectual community should answer nationally and internationally.

\section{References}

Apple, M. W. (2010): Fly and the Fly Bottle: On Dwayne Huebner, the Uses of Language, and the Nature of the Curriculum Field. In: Curriculum Inquiry, 40(1), pp. 95-103.

Apple, M. W. (1971): The Hidden Curriculum and the nature of conflicts. In: W. Pinar (Ed.): (2000 [1975]). Curriculum theorizing: The Reconceptualization. Troy, NY: Educator's International Press.

Boostrom, R. (2008): Transdimensional Curriculum: A Review of The SAGE Handbook of Curriculum and Instruction. In: Curriculum and Teaching Dialogue, $10(1$ \& 2), pp.281-300.

Cochran-Smith, M. \& Demers. K. (2008). Teacher Education as a Bridge? Unpacking Curriculum Controversies. In: M. Connelly M. F. He, \& J. Phillion (Eds.): The SAGE handbook of curriculum and instruction. Thousand Oaks, CA: SAGE, pp. 261-282.

Da Silva, T. T. (1999): Documentos de identidade: Uma introdução às teorias do currículo. Belo Horizonte: Autêntica.

Deng, Z. (2011): Revisiting Curriculum Potential. In: Curriculum Inquiry, 41(5), pp. 538-559.

Eisner, E. W. (1979): The educational imagination: On the design and evaluation of school programs. New York, NY: Macmillan.

Gaztambide-Fernández, R. (2009): Representing Curriculum. In: Curriculum Inquiry, 39(1), pp. 235253.

Glatthorn, A., Boschee, F. \& Whitehead, B. (2006): Curriculum leadership: Development and implementation. Thousand Oaks, CA: SAGE.

Grimmett, P. P., \& Halvorson, M. (2010): From Understanding to Creating Curriculum: The Case for the Co-Evolution of Re-Conceptualized Design With Re-Conceptualized Curriculum. In: Curriculum Inquiry, 40(2), pp. 241-262.

Henderson, J. (Ed.) (2015): Reconceptualizing curriculum development: Inspiring and informing action. New York, NY: Routledge.

Hlebowitsh, P. (2009): Navigating the Normative. In: Curriculum Inquiry, 39(1), pp. 15-26.

Jackson, P. W. (1968): Life in classrooms. New York, NY: Holt, Rinehart and Winston.

Kliebard, H. M. (1977): The Tyler rationale. In: H. Kliebard, A. M. Bellack, (Eds.): Curriculum and evaluation. Berkeley, CA : McCutchan.

Kridel, C. C. (2010): Encyclopedia of Curriculum Studies Encyclopedia of curriculum studies. Thousand Oaks, CA: SAGE Publications, Inc., pp. 230-238. 
Miller, J. (2000): What's left in the field a curriculum memoir. In: Journal of curriculum studies, 32(2), pp. 253-266.

Null, W. (2011): Curriculum: From theory to practice. Lanham, MD: Rowman \& Littlefield.

Null, J. (2008): Curriculum development in historical perspective. In: M. Connelly, M. F. He, \& J. Phillion (Eds.): The SAGE handbook of curriculum and instruction. Los Angeles, CA: SAGE, pp. 478-491.

Pacheco, J. (2012): Curriculum Studies: What is The Field Today? In: Journal of the American Association for the Advancement of Curriculum Studies, 8, pp. 1-18.

Pinar, W. F., Reynolds, W. M, Slattery, P., \& Taubman, P. M. (Eds.) (1995): Understanding curriculum: An introduction to the Study of Historical and Contemporary Curriculum Discourses. New York: Peter Lang.

Pinar, W. (2008): Curriculum theory since 1950: Crisis, reconceptualization, internationalization. In: M. Connelly, M. F. He, and J. Phillion (Eds.): The SAGE handbook of curriculum and instruction. Los Angeles, CA: SAGE.

Pinar, W. (2011): The character of curriculum studies: Bildung, Currere, and the recurring question of the subject. New York, NY: Palgrave Macmillan.

Schubert, W. H. (2009): Curriculum Inquiry. In: M. Connelly, M. F. He \& J. Phillion (Eds.): The SAGE handbook of curriculum and instruction. Los Angeles, CA: SAGE, pp. 399-420.

Schubert, W. H. (2010): Journeys of Expansion and Synopsis: Tensions in Books That Shaped Curriculum Inquiry, 1968-Present. In: Curriculum Inquiry, 40(1), pp. 17-94.

\section{About the Author}

Daniel F. Johnson-Mardones: PhD Candidate, Curriculum and Instruction, University of Illinois at Urbana Champaign (USA). Contact: dfjohns2@illinois.edu

i A first version of this paper was presented at the first European conference of Curriculum Studies held at the University of Minho, Braga Portugal, in October 2013. A second version of it was presented at the International Conference of Curriculum Consciousness, Curriculum Capacities, and Curriculum Building held at Zhejiang University, Hangzhou, China, in November 2014. The former was later published in the Journal of the European Association of Curriculum Studies (Johnson-Mardones, 2015). 